\title{
ТЕАТРАЛЬНА ПЕДАГОГІКА
}

UDC 792.82.071.2.

\author{
Patsunov Valeriy, \\ https://orcid.org/0000-0002-9757-3651 \\ Professor, Honored art worker in Ukraine \\ Kyiv National University of Culture and Science \\ Kyiv, Ukraine \\ v.patsunov@gmail.com
}

\section{THE SYSTEM OF THEATRE "EXPERIENCES" IN THE CONTEXT OF THE THEATRICAL EDUCATION PROBLEMS}

The purpose of the article is to rethink the concept of the theater system "experiences" in the context of the problems of educating the actor and in determining the essence of the creative process of "experiencing" at the present stage of the development of theatrical art. Methodology of the investigation consists of the conceptual methodological core of the study, they are a comparative, semiotic, etymological and analytical analysis of Stanislavsky's teaching about the theater of "experience". Scientific novelty of work consists in analyzing the contradictions inherent in Stanislavsky's teaching about the theater of "experience", in sharpening the attention to the problem of inconsistency with its modern requirements for scenic truth and in determining ways to resolve this contradiction. Conclusions. 1. The division of theatrical art into directions: the theater of "experience" and the theater of "representation" is an anachronism that does not correspond to either the nature of the actor's creativity or the world of theatrical practice. 2. The dogmatism of theatrical education damages the process of educating the actor, hindering the overall development of theatrical art.

Key words: theater of "experience"; theater of "representation"; "system" of Stanislavsky; dogmatism of theatrical education.

Пацунов Валерій Петрович, професор, заслужений діяч мистеиттв Украйни, Київський національний університет культури $і$ мистецтвв, Київ, Україна

Система театру «переживання» в контексті проблем театральної освіти

Мета дослідження полягає в переосмисленні концепції системи театру «переживання» в контексті проблем виховання актора та у визначенні сутності творчого процесу «переживання» на сучасному етапі розвитку театру. Методологія дослідження. Концептуальним методологічним ядром дослідження 
є компаративний, семіотичний, етимологічний та аналітичний аналіз вчення Станіславського про театр «переживання». Новизна дослідження полягає в аналізі протиріч, закладених у вченні Станіславського про театр «переживання», у загостренні уваги на проблемі невідповідності його сучасним вимогам до сценічної правди та у визначенні шляхів розв'язання цього протиріччя. Висновки. 1. Розділення театрального мистецтва на напрями: театр «переживання» і театр «удавання» $є$ анахронізмом, що не відповідає ні природі акторської творчості, ні світовій театральній практиці. 2. Догматизм театральної освіти завдає шкоди процесу виховання актора, гальмуючи загальний процес розвитку театрального мистецтва.

Ключові слова: театр «переживання»; театр «удавання»; «система» Станіславського; догматизм театральної освіти.

Пацунов Валерий Петрович, профессор, заслуженный деятель искусств Украины, Киевский национальный университет культуры и искусств, Киев, Украина

\section{Система театра «переживания» в контексте проблемы театрального образования}

Цель исследования заключается в переосмыслении концепции системы театра «переживания» в контексте проблем воспитания актера и в определении сущности творческого процесса «переживания» на современном этапе развития театрального искусства. Методология исследования. Концептуальным методологическим ядром исследования является компаративный, семиотический, этимологический и аналитический анализ учения Станиславского о театре «переживания». Новизна исследования заключается в анализе противоречий, заложенных в учении Станиславского о театре «переживания», в обострении внимания на проблеме несоответствия его современным требованиям к сценической правде и в определении путей разрешения этого противоречия. Выводы. 1. Разделение театрального искусства на направления: театр «переживания» и театр «представления» является анахронизмом, не соответствующим ни природе актерского творчества, ни мировой театральной практике. 2. Догматизм театрального образования наносит вред процессу воспитания актера, тормозя общий процесс развития театрального искусства.

Ключевые слова: театр «переживания»; театр «представления»; «система» Станиславского; догматизм театрального образования.

The problem formulation. For half a century of work with professional actors and a quarter of the age of theater youth, the author had to conclude that one of the main obstacles to mastering the acting profession is the misinterpretation of both the individual servants of the scene and the individual teachers of theater 
youth of the classical concept of theater "experience" declared a century ago by K. Stanislavsky, which leads to inhibition of the development process as a science about the nature of acting, and the process of forming a new generation of scene artists. Therefore, at the time, the problem of rethinking the doctrine of K. Stanislavsky about the theater system is "experience".

Studies and publications' analysis. The contradictions enclosed in the concept of theater system "experience" for many years were violated in numerous publications by such figures of the scene as V. Nemirovich-Danchenko (1984), M. Chekhov (1986), B. Zakhava (1957), R. Simonov (1960) and many other theoretical practitioners and theorists. Stanislavsky' opponents have doubted his theater "experience" concept, but the dogmatic at the theatrical pedagogical school "preserve" the great director's doctrine, and connected his name, insisting on the indisputable theoretical positions, including those from which the author of the famous "system" has separated. Therefore, the study of ways and methods of the actor's brining up is in urgent need of further development. The purpose of the article is to analyze the contradictions of the system of theater "experience" and to determine the ways of their solution.

Presenting main material. The apologists of the old theatrical school unconditionally believed in the thesis of Stanislavsky, set forth in his article "The Art of Exercise", dated 1918: “...: "We can not divide at the moment of experience between themselves and the spectator. Such a condition is unusual for our nature, which also demands on the stage of a natural, real life according to the laws that it has established itself. She does not tolerate the conventions of the acting game" (1959, p. 71).

This epigram is a continuous contradiction. After all, on the stage our nature does not require "a natural, true life under the laws, by its very establishment", which was demanded by the actor Stanislavsky, namely the game, conditional in its nature. Namely, there are two natures: human and actor and they have perfectly coexisted for over two thousand years, not only coexist, but also need each other. Remember, a person needs to play from the very first day of his birth, and he realizes this need throughout his life, not only on the stage, but also in everyday life. Subsequently, while he was working on the performance of "Othello", Stanislavsky would change his previous opinion to the opposite one: "First of all, one must take care not to build a role only actor's temperament. Let him come by himself, that's fine. When it does not happen, let the tech help. Without these relaxing conditions, playing such a difficult role as Othello's suicide" (1945, p. 228). At the end of his life, this thesis would be unfolded by the director, as we learn from B. Zahavi' memories: "Shortly before the death of KS, on the day of his 75th birthday, I, among other comrades from Vakhtangov's Theater, had the good fortune to talk with him. This, by the way, it was talking about Shakespeare' tragedy. And we heard from K.S. words that made 
a really stunning impression on us that time. He said: "To play such roles as Hamlet, Othello, Richard, Macbeth, from beginning to end on feeling - it's completely impossible. On this, human power is not enough. Five minutes on feeling and three hours on high technique there is only one way you can play Shakespeare" (1957, p. 44-45).

Consequently, if the technique replaces the process of experience with the actor almost throughout the whole role, then this is a direct indication not of the theater "experience", which devoted Stanislavsky's life, but the theater "evasion", with which the director ruthlessly fought. Stanislavsky's statement crosses not only his long-standing theory of two theatrical directions: the art of "casting" and the art of "experience," but also the main thing of his life, it is the creation of the theory and practice of the theater "experience".

IS Stanislavsky against Stanislavsky? Is that a suicide? No, this is a wise man's enlightenment who lived his life in doubt, struggling every day with each of his discoveries, testing it for strength, and resolutely giving up yesterday's hobbies. This position allowed him to be "sighted" to the last breath, while in the relentless process of cognition unfathomable mystery man. However, they do not see this "iconographers" of the great director, continuing to insist primarily on the feelings of the actor, ignoring the technique of their modeling, which involves persistent control both in content and in the form of the resulting image, in the end, as a result of this living process of creation.

One of the first who opposed his teacher was an outstanding actor, director and teacher M. Chekhov. He strongly objected to the "holy of holies" of the Stanislavsky school, there was the process of "experience": "Experiences on the stage are unreal. All feelings, all desires, all experiences of your scenic image, no matter how strong they are, they are all unreal. They should not be real ... (...) Chaliapin said: "It's not me Susanin crying, it's me crying, because I feel sorry for him" (1986, p. 266-267).

Several years after the death of Stanislavsky, his closest associate, co-founder of the Moscow Art Theater V. Nemirovich-Danchenko recognized the incompatibility of the term "experience" with the nature of acting: "Experience. As soon as we start talking about this sphere, we will see very quickly that the word itself does not already satisfy those concepts those are embedded in it. The "actor of experience" and the "actor of representation" do not seem to me so much antipodes, that is, opposites, as it was supposed, when Stanislavsky had just begun to introduce his pedagogical-theoretical reflections into a clear, definite channel. And what we often see on a number of practical examples, how the "actor of representation" really experiences or the "actor of experience" deftly and skillfully represents, it will lead by all means to the fact that the definition of "experience" has been replaced by something else" (1984, p. 125). 
If Nemirovich-Danchenko, after Stanislavsky, cancels the "experience", which "no longer satisfies the concepts that have been embedded in it, "then by this he crossed the boundary on which the new vocabulary of acting art should appear. And for this a new Stanislavsky should be born. And while he was not born, we hear and see the last quarter of the twentieth century the echo of his genius in the direction of P. Brook, L. Dodin, A. Vasiliev, E. Grotowski and other representatives of the new wave, which brilliantly denied the creation of Stanislavsky's own theaters and schools.

Student of Vakhtangov's director R. Simonov claims: "Our theater was harmed by various interpreters and false students of the school of "experience". They distorted the "system" so much that the actors forgot how to create images, characters, and the modern theater that follows the school of experience no longer infects or worries" (1960, p. 15) cording to R. Simonov, dogmatists distorted not only the essence of the art of experience, but also the art of pretension. He calls "clear, free words" "representation", "game" from such a scourge of viciousness, which they were covered by various pseudo-talkers of the teachings of the great Stanislavsky" [the same].

Outstanding Italian tragedian Tomaso Salvini admits: "The actor is called upon to fulfill a dual role: he does not feel very much himself; It is necessary that he make others feel, and this he will not attain without self-control" (1981, p. 59).

Vakhtangov's pupil B. Zakhava continues the theme of the duality of the actor: "Nobody can truthfully" represent "not" experiencing, as one can truly "experience" without imagining. (...) When the live experiences of the actors leave the theater of "representation", and from the theater of "experience" - everything related to the "representation", that is, the skill, technique, skill, artistic calculation, both of them - both the theater of "representation" and the theater of "experience" are deprived of what informs art of its social significance, they lose the main thing the ability to reflect life... (...) And then it remains, in one case there is naked technology, divorced from the truth of life, in another case there is an experience devoid of artistic form, devoid of artistic form - two hypostases, two varieties of art so hated by Stanislavsky.(...) That's why I'm for the synthesis, for the connection. That's why I immediately and for the "Stanislavsky system" and for "presentation". That's why I'm for Ruben Simonov ... ... That's why I'm for Vakhtangov. In Vakhtangov there are Stanislavsky, Nemirovich-Danchenko, and even Vsevolod Meyerhold" (1957, p. 45).

How do not we remember Danny Diderot here? "The actor cries with real tears, but his tears flow from the brain" (1966, p. 24).

So what, finally, is the difference between pretension and experience? Let's remind everyone of the well-known children's hysterics that are breaking the hearts of compassionate parents. However, after satisfying its quirk, the child immediately 
silences and continues to play with dry eyes. In these cases of childhood heart attacks, world medicine has not been documented. Millions of adults have been caught for this millennium for this childhood trick. However, what category does this baby art refer to the art of "experience" or to the art of "pretension"? The conclusion is that in the theater, "the experience" the actor has to "blow out" the process of "experience", as the child does in the above example, and in the theater, "casting", the actor must "manipulate" the process of "eviction" (tautology is forced), as demonstrated by the play "Princess Turandot" by E. Vakhtangov. Actually, in the theater of any type, the actor must not drown in feelings, and masterly master their emotions and feelings, his sensory keyboard, as a piano keyboard piano. It is under these conditions that the creative process of creating an image can be productive and effective.

And because the laws of physiology "control panel" emotions and feelings of a person (sensory keyboard) is a nervous system, the author will allow himself to define his own definition of the concept "actor drama theater":

The drama theater actor is a man who owns and manages his nervous system to create a stage image and radiate it into the spectator's space.

If a violinist has a violin instrument, a pianist has a piano, and then the actor has his own nervous system. It is on its keyboard that he plays. Therefore, the development of the acting profession requires, first of all, mastering the art of managing own nervous system to create a scenic image. And as for "shedding it into the spectator's space," this epigram is the subject of author's separate scientific work.

And finally. Whatever the doubts, some of the theoretical gains of Stanislavsky, this most prominent figure in the history of the world theater, there were not subjected to certain provisions of the theoretical achievement by these actions we fulfill his testament to the descendants to unceasingly seek and seek out the truths in the process of knowing the nature of human-man. And in the world of the collapsible process of recognition, we will have a moral enthusiasm; there is the most profound follower of Stanislavsky outstanding director G. Tovstonogov:

"Popularizers and ignorant people did not understand that the system rejected all the rules in its own way. The system does not enslave in any frame. On the contrary, it liberates his strength, opens the way to a big world. Everyone should open this system in himself or herself. System is faith to nature. Like nature, it moves, changes, lives. The system is a rebellion against dogmatism. What kind of blind man must one be to understand dogmatically?" (1966, p. 112).

Scientific novelty of work consists in analyzing the theoretical contradictions of Stanislavsky's theory about the theater "experience", in the inconsistency of this teaching with modern requirements to the stage truth and in the analysis of the dogmatism of theatrical education. 
Conclusions. The modern school of upbringing the actor absolutely needs "restart", liberation from dogmatism, methodological upgrading, rethinking the concept of theater system "experience", developing innovative ways and methods of managing the actor by his nervous system to create a stage image and radiate it into the spectator's space.

\section{Бібліографічні посилання}

1. Дідро Д. Парадокс про актора. Київ : Мистецтво, 1966, 147 с.

2. Захава Б. Е. За синтез театра «представления» и «переживания». Театр. 1957. № 1. C. 44-45.

3. Немирович-Данченко В. И. О творчестве актера : хрестоматия. Москва : Искусство, 1984. 624 с.

4. Сальвини Т. НБсколько мыслей о сценическомъ искусствБ. Артист: театр., муз. и худож. журн. 1891. № 14. С. 58-61.

5. Симонов Р. Е. В центре - актер. Театр. 1960. № 4. С. 15.

6. Станиславский К. С. Режиссерский план «Отелло» Москва ; Ленинград : Искусство, 1945. 392 с.

7. Станиславский К. С. Собрание сочинений : в 8 т. Т. 6. Москва : Искусство, 1959. $466 \mathrm{c}$.

8. Товстоногов Г. А. О профессии режисера. Москва : ВТО, 1966. 360 с.

9. Чехов М. А. Литературное наследие : в 2 т. Т. 2. Москва : Искусство, 1986. 1069 с.

\section{References}

1. Didro, D. (1966). Paradoxes about the actor. Kyiv: Mystetstvo.

2. Zakhava, B.E. (1957). For synthesis of theater "representations" and "experiences". Teatr [Theatre], no. 1, pp. 44-45.

3. Nemyrovych-Danchenko, V. (1984). About creativity of the actor. Hermitage. Moscow: Yskusstvo.

4. Salvini, T. (1891). A few thoughts about the theatrical art. Artist: Teatralnyi, muzykalnyi i khudozhestvennyi zhurnal [Theatrical, musical and fiction magazine], no. 14 , pp. $58-61$

5. Symonov, R.E. (1960). In the center - the actor. Teatr [Theatre], no. 4, pp. 15

6. Stanislavskiy, K.S. (1945). The director's plan for "Othello". MoscowLeningrad: Iskusstvo.

7. Stanislavskiy, K.S. (1959). Collected Works: in 8 vol. Vol. 6. Moscow: Iskusstvo.

8. Tovstonogov, G.A. (1966). About the profession of Art-directors. Moscow: VTO.

9. Chekhov, M.A. (1986). Literary heritage: in 2 vol. Vol. 2. Moscow: Iskusstvo.

(C) Паиунов В.П. 2018

Стаття надійшла до редакиії 29.03.2018 